\title{
Cultural Dimensions of Economic Development: A Case of UAE
}

\author{
Gouher Ahmed1, Aqila Rafiuddin² \\ ${ }^{1}$ Skyline University College, Sharjah, UAE \\ ${ }^{2}$ American College of Dubai, Dubai, UAE \\ Email: gouher@usa.net, aqilarafi@gmail.com
}

How to cite this paper: Ahmed, G. and Rafiuddin, A. (2018) Cultural Dimensions of Economic Development: A Case of UAE. Theoretical Economics Letters, 8, 2479-2496. https://doi.org/10.4236/tel.2018.811160

Received: April 20, 2018

Accepted: August 19, 2018

Published: August 22, 2018

Copyright (c) 2018 by authors and Scientific Research Publishing Inc. This work is licensed under the Creative Commons Attribution International License (CC BY 4.0).

http://creativecommons.org/licenses/by/4.0/

\section{cc) (†) Open Access}

\begin{abstract}
Economic development, which is sought all over, is a long-term increase in national and per capita income for higher consumption and happiness. It may seem lacking in finer things that go under the name of culture. As such, this study sets to examine the cultural dimensions of economic development, with the case study of the fast-developed small nation of the United Arab Emirates (UAE). The giant developing India is also drawn upon. The objectives of the exercise are to find out the nature and dynamics of economic development and its cultural dimensions or content and thereupon draw policy implications regarding economic and cultural development. The interesting conclusions that follow from the exercise are that, there are invariable cultural dimensions to economic development and that a cultural sector emerges in the course of economic development. More emphasis needs to be given to culture in development policy and planning, without culture, economic development is not wholesome, as the UAE is amicable of wholesome holistic development.
\end{abstract}

\section{Keywords}

Cultural Development, Cultural Dimension, UAE Cultural Dynamics

\section{Introduction}

Economic development has been continuously sought after the Industrial Revolution (1760-1840), commencing in England and spreading to the rest of the western world. Since World War II (1939-45), the hitherto underdeveloped world of Asia, Africa and Latin America (LAM) have been constantly moving towards economic aplenty of the USA and other developed countries. As a result, China from nowhere has emerged, in the last 40 years since its "free econ- 
omy" reforms of 1978, as the second economic power after the United States of America and is aiming to become the No. 1 economic power, replacing the United States of America. There seems to be a marathon race of economic development of the countries, each competing to reach the goal post of highest possible per capita income and even more that represents a high standard of living, represented by a big basket consumption of goods and services, as economic development today is a measure of the rising and falling economic and other fortunes of nations. It is freedom from poverty to plenty. It has valuable cultural content too, which is not highlighted.

Culture, which stands for refinement of an intellectual and artistic taste, values, customs and tradition [1] may seem not to have a place in the hard drive of economic development for economic aplenty or consumerism. The only culture which economic development may seem to breed is the culture of consumerism or materialism or high consumption.

Adam Smith, who is regarded as the patriarch of economies and economic development had theorized that nations live to increase their material belongings, which he called National Wealth in his all-time classic The Wealth of Nations (1776), which can be said to have heralded the era of model economic development, [2], "Wealth means only material goods like bread-and-butter, clothing furniture and other such things, with no place for finer things of life that go under the name of 'Culture'". Is there no place for culture in economic development which seems to be the only culture of the current highly materialistic age of no great values, with the great global financial crisis of 2008 greatly attributed to the fall of moral values in the bankers handling huge public deposits? Is there a place to culture in economic development? This is, in fact, an important and interesting question to investigate.

This study sets to investigate the cultural dimensions if any of economic development, which appears to be interpreted in purely economic or material terms, with a special reference to the new and fast developing Arab State of the United Arab Emirates (UAE), of ancient culture and civilization. As against economic development seemingly concerned with material things, culture is concerned with values and finer things of life which are quite valuable.

Culture is identity, and it is the very lifeblood of human existence. It is indicative of the freedom of choice as well as the bonds strengthened by communal expression. It connects the individual to their past and present and is the cornerstone of the rebirth of civilizations. Concerning the UAE of this study as an illustrative and illustrious example of the bondage between economic development and culture (E \& C), The City of Al Ain in Abu Dhabi as UNESCO World Heritage site, and in 1988 the Emirate of Sharjah was named by the UNESCO as "The Cultural capital of the Arab World" and in the 2014 "Capital of Islamic culture by the OIC [3], which are rare cultural distinctions of the new 'model"' Arab developing state, known for its opulence and lifestyle.

The exercise is a modest contribution to the prospects of culture and cultural 
development in the seemingly materialistic age ushered in by the long years of economic development. The prospects of culture and cultural development may seem bleak in the present age of economic development of the under-developed countries struggling for a good economic living, first and foremost among which India may strike as a nation of very ancient civilization and rich culture but greatly poverty burdened still. But, there too, it is shown, culture is standing between a good grounded and spreading its wings. Regarding the young state of the United Arab Emirates, culture is brought out to be as good as the soul of the "miracle" like the economic development of the country. It is very rarely highlighted in the economic development of the UAE, which is brought out clearly by this exercise. And, also of the cultural push of India, and getting the UNO to accept 21 June as International Day of Yoga, an ancient system of bodily and breathing exercises and meditation to keep the body and mind in a fit order.

Not the least, theoretically establishing culture as the Fourth economic sector, along with the primary, secondary and tertiary or Agriculture, Industry and service sectors, as the non-economic sector of rising importance. Significantly, the USA is found to be a good cultural case. The singular contribution of the exercise in establishing the UAE as a model of cultural development.

The study is organized around Objectives, Methodology and Data, Literature Review, Cultural Barriers, Culture-Based Development, Underdeveloped Countries, Culture of Development. The United Arab Emirates-Economic and Cultural Development, Summary and Conclusion.

Objectives, Methodology and Data

1) To investigate the nature and measure of economic development

2) To examine the dynamics of economic development

3) To Identify the cultural dimensions of economic development

4) To draw summary and conclusions and policy implication of economic development and cultural linkage.

The methodology of the study is to study the conventional interpretation of economic development to view it as a long-term economic run resulting in greatly increased national and per capita incomes, which in turn cause higher levels of consumption and utility or satisfaction and individual and social welfare. The traditional economic sectors are agriculture, industry and services a 3 -sector model of economic development, which however does not tell the full story of economic development without an addition of culture and a cultural sector, thus, making economic development a 4 -sector development. There is, in fact, a rising call for culture-based economic development of values and environmental wellness of which the United Arab Emirates appears to be a model case, notwithstanding its desert location.

It is not just about development, but culture-based development which appears to be the call of the day. There is a rise of a cultural school of economic development without culture and a value dimension, the UNO espoused sustainable development is a far cry [4]. 
As such, the data of the exercise refers not only to economic development data of national and per capita income and burgeoning consumption levels, but also to cultural development in terms of, say, the institutions of culture as museums, art galleries, theatres and like and cultural business like tourism which is to have an experience of the cultural ambiance of a country, as food, dress, historical and modern monuments and sites. For example, BurjKhalifa, Dubai is an assertion of the modern architectural identity of the UAE, and the Arab world in general.

The BurjKhalifa (2010) standing at an awesome and admiring height of 828 meters is not only a symbol of the Emirates economic development but also of its cultural advancement and architectural renaissance. It's a cultural manifestation, among other things.

\section{Literature Review}

To take a look at economics and economic development in terms of representative works, the attitude of the two may appear to be one of indifference towards culture, the problem of supplying to the material needs of the people being immense in itself.

The presumption of the study is that there cannot be real and holistic development without a cultural dimension, and cultural sector development. Apart from agriculture, manufacturing and services-the traditional primary, secondary and tertiary sectors-there is invariably a cultural sector that needs an attention. For, man does not need bread alone but also other things like Art, literature, dance, drama, music, etc., which must also experience revival and advancement and be flourishing along with national advancement. Identification of the cultural sector is a methodological exercise of this study with reference to the United Arab Emirates. With economic development, there is a rise and fall of sectors. The importance of agriculture is taken for granted to decline and that of manufacturing and services to increase. What happens to the sector? It's also likely to rise, as demand for cultural goods and services like cinema, TV, shows, music, etc., rises with the increase in income and population, tastes, etc.

The history of economics and economic development is long and varied, following which a representative presentation is made of the two subjects which bring forth the nature of economic development.

Meanwhile, it's also a presumption or hypothesis that without an adequate cultural dimension, economic development falls short of the public or popular as well as learned expectations of economic development. The usual data considered for the study of economic development is population, national and per capita income, infrastructure, trade, etc., but it should also be culture and cultural infrastructure and creative arts, as there is always an active creative class of culture. [5].

The premise of economics, the mother science of economic development, is that humans are bundles of wants for the satisfaction of which the whole life of humans is spent to meet them. There is no end to the stream of human wants. 
There is a hierarchy of wants, namely, Necessaries Essentials, Comforts, and Luxuries, but the means to satisfy these wants in the form of land, labor, capital and entrepreneurship are limited [6]. The Nobel Laureate Prof. Samuelson whose text Economics is the most popular text of economics across the globe, talks of the relationship of economics with other social sciences but not culture. The index of the voluminous work doesn't carry the word culture.

Today, super-luxuries are added to the list of human wants and super brands to satisfy them. But, the concept of unlimited human wants doesn't rule out cultural wants and needs and aspirations which are part and parcel of human life and any real human development. There, however, may be a conflict between economic and cultural needs, with economic or material needs or monetary considerations taking a precedence over non-material or cultural needs.

The first law of economics is unlimited wants. The next economic law is scarcity, which is the limitation of means, material and monetary, to satisfy crowed and economic needs that grow with the passage of time. The third law of economics is an alternative use of resources, which may create a conflict between the economic and cultural needs, the bulk of the population preferring the first to the second.

A Stellar name in Economics is Alfred Marshall, according to whom economics is a science of ordinary business of life of satisfaction of unlimited wants with the limited resources of money and material things [7]. His book the Principles of Economics is the first modern text on the subject, which too doesn't take of Economic and Culture, as if culture is alien to Economics, as if the ordinary business of life is enough or more than enough a subject matter for Economics. No wonder, then, economics is generally viewed as a dry-subject. But, today, there is an active branch of economics called Cultural Economics and there is an active association for cultural Economics Association (ACEI) which holds annual international conferences on cultural economics and runs a Journal of Cultural Economics, bringing culture very much into the fold of economics and economic development, enlivening the subjects of economics and economic development.

As if the constraints on the satisfaction of the wants are not enough, Malthus had introduced the barrier to all human progress and any cultural commitment in the form of his famous Malthusian Law of Population, which is that the growth of the population always outpaces the growth of food supplies. Food and population, with food as the first requirement of population, have a tendency to grow at arithmetic and geometric rates, respectively with population always facing the scarcity of food and lives a miserable life of hunger, famines, ill-health, diseases, wars [8]. Accordingly, the presumption mankind can never rise above the bare subsistence level with no resources for finer things of life, as culture and such things. As if confirming Malthus's gloomy predictions, the world, especially the underdeveloped world, is well known to be afflicted by a great deal of poverty. These people have no time to think of say culture. Still, culture, which every 
country has its own built over a long, long period of time cannot be expected to be away from economic consideration, as say, fairs, and festivals, etc. which bring joy to one-and-all. Man is not only an economic but also a cultural being, and economic development is dry sans culture, and cultural development.

Another classical economic thinker Ricardo too had a very gloomy prediction of economic future, because of the limitations of land, a fixed natural resource or capital, which would be felt to be increasingly scarce with increasing population and demand for more and more food. Further, it is subject to the law of diminishing returns, which is when more and more capital and other factors of production, are applied to the same piece of land it will go on giving less and fewer returns agricultural output. A gloomy economic and cultural picture indeed. So, by the nature of the physical world, material seems to dominate non-material or material needs over the cultural ones.

It is a different thing that these gloomy predictions had not come true. The wheel of economic development had not come to a halt but had gone on moving with no seeming stoppage. No doubt, populations had grown by leaps and bounds with the good earth looking to be over-crowded or over-populated and polluted too. There is climatic degradation and thousands of other ills, notwithstanding of which the cart of economic development keeps galloping, proving Ricardo too to be wrong [9]. Today, developed nations like the United States of America have good agricultural capabilities. Nevertheless, population and food problems weigh heavily upon the developing countries like India and the world in general. The world is not hunger-free.

The world in 2018 is celebrating the $200^{\text {th }}$ year of the birth of Karl Marx associated with the collapse of capitalism and ushering in of a communist society of equality and labor governance and his famous work is Das Kapital [10]. A counterpoint to Marx was offered by Schumpeter (1912 and 1934) and his theory of economic development is of entrepreneurship and its innovations that would like the economy on a long or forever development path. But, it is the school of Smith, Schumpeter and Rostow, standing for fulsome development appears to have turned right in the western developed world in all respects including culture.

Yet, it is interesting to note that these optimists too had nothing to say of culture, occupied as they were with ample production of goods and services.

Malthus and Ricardo pessimism regarding the prospects of economic growth and economic betterment had proved to be wrong and Adam Smith, the father of economics and economically developed with his main thought of unlimited economic development till a long-long time until the economy reaches a happy state of equilibrium through division of labor, specialization, free markets and free trade had turned out to be prophetic, and his, Smithian development principles unfailing [2]. The market by implication has to take cognizance of cultural goods and services, and cultural institutions to come up and a cultural sector emerges. 
The result is visible all over the western world at the vanguard of economic development, especially the United States of America (USA), in sky-high buildings, well-stocked shopping malls, cars-crowded streets and highways, super-rich restaurants, cinema houses, theatres, music halls, so and so forth. There is a culture of consumerism all-over, of chasing FMCG-Fast Moving Consumer Goods [11]. A noted American economist, Rostow (1962) had sketched the process of economic growth from start to end, which is of a very high-end. Rostow's stages of economic growth are five, namely, 1) Traditional Society 2) Preconditions for take-off 3) Take-off 4) Drive to Maturity and 5) Mass consumption. Thus, the end of economic development is seen to be high consumption or consumption of goods on a mass scale.

Thus, the cultural product of economic development at its end if any is seen to be the culture of consumerism. During the time Rostow's work, only the United States of America was at the end-stage of economic development, which he called the Age of Mass Consumption. Man becomes just a consumption machine. The US, cannot be written off as a bad cultural case in spite of being a good case of economic development. It's is a culture of democracy, free judiciary, enterprise, exploration, enquiry, philanthropy, innovation, fundamental scientific research, high endowments, free speech, outstand sports performance in the Olympic Games, outstanding educational institutions, Nobel Laureates, world-class companies, great CEOs, great Cinema, moving music, literature, journalism, discipline, military might, great army, mingling of cultures, openness that awes and inspires the world. In sum, as a result of the free enterprise development of its economy, there is a holistic or all-round development of the US economy and society. The US's Oscar awards function is perhaps the most dazzling in the world. It has a great culture of Science, dominating Nobel Prizes. It is a different matter that the US economy is said to be under trade pressure from China [12], in spite of being the No.1 economy in the world.

\section{Cultural Barrier}

The newly developing countries are said to have a number of hurdles in the way of their economic development. Still, poverty is a good deal of their lot. The newly developing countries are said to have first cultural barriers to their development. What does culture hold in the case of new developing countries such as India? An aid or a hurdle? As, often a difference is made between Eastern and Western cultures, as materialistic and spiritualistic, respectively. Are old cultures that of, say, India anti-developmental? Yes, according to some colonialist who ruled India during 1757-1947, as Anstey (1952) [13]. Disproving this cultural barrier thesis, India has made rapid strides in economic development since Independence, an example of which is food imports to food self-sufficiency. India's first Prime Minister (1947-1964), well before Independence, had foreseen both economic and cultural resurgence of Independent India [14]. Mahatma Gandhi who had led India's independent movement had a dream of India of wholesome 
development in tune with its rich culture of upright character, simple dress and diet but of intellectual brilliance in all fields of culture [15]. In recognition of the value of Indian culture, the UNO had declared $21^{\text {st }}$ June as International Yoga Day, Yoga is a form of physical and mental exercises conducive to physical and mental well-being.

\section{Culture-Based Development}

As against the above development school, there is a cultural school which advocates culture-based development (CBD). While Samuelson, Nobel Laureate in Economics (1970) and whose text Economics has been a standard text for generations of students across the globe found no relationship between economics and culture, But, Thorsby (2001) treats them as quite allied [16]. The cause and effect relationship between culture and economic development is $C \rightarrow D$, not $D$ $\rightarrow \mathrm{C}$, as per the new cultural school of development.

Among others, there is said to be a new creative class enriching the field of culture and putting culture at the Centre of the new, socio-economic set-up. [5]. For example, there is a start-up movement in economic development and there is also a start-up like things in the field of culture.

Culture-based economic development is very much in evidence in the USA [17], which may be called "new" US development, at local level. And, what is more, it is found promotive of the economic and social well-being of the local communities, not just localized economic development. And, more cultural diversity means more impact of it on socio-economic development [18]. As long back as 1973, Bourdieu called for cultural and social regeneration through education, knowledge and societal change, making culture a dynamic concept [19]. Culture based development is a new school of development which intends to put culture as an important creative factor of development.

Tubadji [20], noted for culture-based development thesis, calls culture a dynamic development factor, and development as a "sole function" of culture, and in association with Pelzel [21] calls it an "invisible" factor of development, obviously not as visible as the traditional factors of development of land, labor, capital and organization or entrepreneurship.

Not Surprisingly, cultural diversity, as in US cities of many nationalities and culture to have more development impact, which explains the economic vibrancy of major US cities, especially the all-awake New York [22]. In a seminal work, Granato et al. (1996) argue not just in the matter of development but human progress which is values based. Thus, it is another angle in the CBD theory. That is, it is not just culture but cultural values that are important for development. Accordingly, development needs to be values based. In the same vein of as the study of Granato et al. [23]. There appears to be a considerable weight in the values based economic development in the light of the experience of the global financial crisis of 2008, greatly attributed to big banking's "greed". The UAE is a good example of value-based development, the authorities, there were serious 
about a green and clean economy which is Islamic principles based.

Marini [24], there is a cultural evolution from the traditional culture of religion and obedience and tolerance to the modern one of personal achievement and the most-modern one of ambition. There is an economic evolution too from a traditional economy to the modern and post-modern ones. But in the process of this cultural and economic evolution, it is quite well-known that the old-world and old traditional culture values of honesty and work appear to have been greatly weakened.

In an expansive study across Europe, Tabellini [25] finds culture and its institutions playing a significant role in economic development. Culture, like services, may become a later day development factor. And, Bowles [26] is of the view that culture means not just values but also preferences or wants, cultural market and economic institutions to backup consumer markets-all that go to make up what may be called a cultural sector like agricultural sector, industry, services-sectors. Amidst all this, Petrakis and Kostis [27] find economic development quite promotive of cultural development, because this is an age of economic development of the under-developed countries, which is the second development run, the first being of the developed countries. The "bread-and-butter" their only concern with little thought and resources to spare for culture and cultural development? Are Oriental cultures barriers to the economic development of underdeveloped countries? The cultural question needs to be addressed, and is found negativated in the aforesaid study.

Thus, a close link is established between culture and economics and economic development and cultural development. In fact, the new culture based development school is for culture-based and cultured or value-based development. This is forcefully voiced by Harrison and Huntington at the dawn of the new century (2000) [22], culture stands for values which are the determinants of human progress at large. And, Baycan and Nijkamp [18] thesis is that the cultural diversity in turn produces socio-economic diversity.

Thus, Literature Review, and also the experience of the developed countries drives home the point that culture is an inescapable point of development. And, also there are no cultural barriers to the economic development of the underdeveloped countries, which commenced their development Journey after long periods of colonialism and independence after World War II (1939-1945), as India, they, first call for a culture of development.

\section{Under-Developed Countries}

These are the countries of Asia, Africa and Latin America in general, hitherto under colonialism, setting on the course of development in the new development era following the end of Second World War (1939-45) marked by the establishment of the world bodies-UNO, World Bank, IMF and others.

A lot of Under Developed Countries or Least Developed Countries is expressed by the expression of the vicious circle of poverty. By implication, they 
are culturally backward or underdeveloped and it is said to be an obstacle in the way of their development. The culture of development can be envisaged as one of thrift, saving, rationality, scientific outlook, entrepreneurship, education skills, and such, which are well-known to be at the back of phenomenal development of the western world into which people from across the globe want to migrate, whether legally or illegally, and enjoy the economic comforts of the nations of the west. This westward migration whether by plea or force is one greatest fears of the west and was behind the exit of Britain from the EU. Migration, of course, of capital, labor, entrepreneurship, is a modern-day phenomenon. What is striking is many developing countries are silent, openly encouraging the phenomenon.

\section{Culture of Development}

Economic development is held to be a function of enterprise and entrepreneurship with the help of the factors of production of land, labor, capital and organization, Schumpeter [28]. It is entrepreneurship, through a continuous stream of Innovation of goods, factors, processes, that takes the economy forward. It is the culture of enterprise which is at the back of economic development which is increasing production of goods and services that go into human consumption and further production over a long period of time, Kindelberger [29]. There, therefore, appears to be a need to develop a different culture for development, namely, the culture of development, which, however, is not for acquiring under serving wealth by fair or foul means or at any cost, but a culture of thrift, saving investment, training education and productivity. It is the culture of economic development which doesn't come into conflict with any other culture or culture in general, the promotion of which is incumbent upon e-development. In the post-world-war-II of new development era of new developing countries, many nations have yet to have a developmental breakthrough and fly off.

Still, the eastern cultures are generally held by western scholars not so conducive to economic development, being spiritualistic or otherworldly. For example, the continues backwardness of India during the long British regime was largely held to be due to its cultural factors of religious conservatism of treating some classes of people, including the Europeans, as people of lower class with unwelcome food and other habits caste system, untouchability, dislike of manual labor by the so-called upper castes and classes, moksha or salvation as the supreme aim of life, inwardness and so on so forth Anstey [13]. Economic development, however, is sure to overcome any such cultural barriers and establish the regime of development in all spheres of life. For the lure and magic of money is so powerful to the high and low. For example, population control and family planning once was a taboo but today it is widely accepted as a key, among other things, to family health, wealth and welfare.

Today, overcoming, automatically, whatever alleged or real cultural barriers to growth, India is known to be one of the fastest developing countries in the world 
with a growth rate of around 7 per cent that is expected to reach 8 per cent and even a 2 digit one [30], with a vibrant and well diversified, world-class well taken care cultural sector for which there is a Ministry of Culture at the Government of India level as well as the state government levels, the states numbering 29, besides 7 political and administrative unity called union territories (UT). India with a great cultural heritage, cannot be devoid of culture as one of its principal co-development component E-development, which doesn't mean just an increase in goods and services for people to give a happy life of material comforts but also flourishing of all finer things of life that come under the label of culture. Through great centuries across the globe, India has been famous for its culture, civilization, philosophical thought as well as wealth, even the mighty Roman Empire fearing the loss of its gold to Indian exports cannot be compensated by any amount of material wealth. India may be poor economically but is rich culturally. Independent India's first Prime Minister, Pundit Jawaharlal Nehru (1947-64) writes of the rich culture of the Indian masses quite movingly in the following words, Nehru [14].

"Thus, I saw the moving drama of the Indian people in the present. They may be poor but they are cultured people of good character and conduct, and could often trace the threads which bound their lives to the past, even while their eyes were turned towards the future. Everywhere I found a cultural background which had exerted a powerful influence on their lives. This background was a mixture of popular philosophy, tradition, history, myths and legend, and it was not possible to draw a line between any of these. Even the entirely educated and illiterates shared this background" Proceeding, Pundit Jawaharlal Nehru writes of the familiarity of the people with the great epics of the country, the Ramayana and the Mahabharata and their virtuous and villainous characters and their morality". Nehru during his reign of 17 years (1947-1964) laid the foundation for a developed India, and also for its cultural regeneration by establishing institutions or academies for different cultural fields as music and drama. India is a good example, with a population of 1.39 billion (2018) of economic development with a cultural dimension UN [4].

Thus, the culture and civilization of India are somewhat different from being mostly philosophical and otherworldly. This lends some values to India's economic development, which is economic development not at any cost but in a balanced, sedate and cultured way. For example, Mahatma Gandhi, the father of India Nation, who could have enjoyed any luxuries had led a life of the hermit in Ashrams or hermitages but engaged with the problems of the country's Independence and its reconstruction. According to him "India is essentially Karmabhumi (Land of Duty) in contradiction to Bhogabhumi (Land of enjoyment)". Mahatma Gandhi famous saying that needs to be inscribed every development program is that we have enough for everyone's need, but not greed. As Mahatma Gandhi was for economic and social and cultural regeneration of the country even well before independence in a wholesome way, from agriculture 
and village industries, and a New Education which would instill dignity of labor and skills [15]. Mahatma Gandhi's is green and clean development in tune with the culture of the country of "simple living and high thinking". Thus, however, does not mean embracing poverty. Poverty in India is still widespread, calling for the further economic development of the country, as no culture stands for poverty and India's least.

As such, there is no conflict between culture and economic development. According to Gandhi culture is one of the richest endowments of India. The nation has a rich cultural plurality, with all cultures, including rich tribal culture flourishing with the economic development of the country.

But, alas, in its quest for global level economic development, India does not appear to be taking much of its rich cultural heritage as its priceless antiquities are being stolen and smuggled abroad, depleting the fabulous cultural wealth of the country. The drain is said to be in billions of USD. The country should know how to preserve and protect its rich cultural heritage and the cultural drawn needs to be subtracted from the nations GDP. India today is culturally a more known country and also its cultural development along with its economic development. India's development is democratic development based on the economic and cultural needs of the country and its people.

Economic development, which is a continuing change from production side in raw materials, processes, machinery, packaging, advertising and marketing of goods and services and their sales or shopping, quite imaginably, brings in its wake cultural changes in the way people think, live dress, move around entertain themselves, etc. a new economic culture-a culture of corporations, malls, casinos, pubs, clubs, gaming centers, of travel and tourism, lavish weddings and so on and so forth which is all pervasive across the globe [31]. It is an extensive topic to be dealt with, which cannot be taken up in the limited space of this article. Culture is a fascinating subject which is multi-dimensional. There are cultures-within-cultures. India, for example, famous for cultural plurality. There also appears to be a clash of cultures, as of East and west. But, such a clash, if any, is to be called for, as the world is a mingling place of many cultures with cultural exchanges. For example, Arab food is becoming popular in some places in Hyderabad, India for its wholesomeness.

One also watch's with dismay the all-pervading importance of money (M) overall, else, especially Morals, the recent (2008) global financial crisis being widely known to be due to "greed" of making money by all means, fairs and foul, Amponsah and Ahmed [32].

There seems to be a fall in cultural values of honesty, hard work, discipline and dedication, apart from the declining pursuit of fine arts and crafts either as hobby or profession. Morality is as important as material comforts and luxuries. Does it mean that economic development is lacking in the right cultural content? Panama papers and such others call off and point out to corruption at the higher stages of politics, business, etc. What is the use of culture without character? 
Does culture get corrupted with the passage of time and rising affluence? It shouldn't.

Notwithstanding some serious doubts regarding the character and content of culture, it is a fact that culture a dynamic factor which changes over time and space depending upon the socio-economic, religious, technological, and other factors. There is also mixing and mingling of different cultures, as in India.

"It stands for synthesis of the different cultures that have come to stay in India, that have influenced Indian life, and that, in their turn, have themselves been influenced by the spirit of soul", Gandhi [15].

\section{Cultural Dynamics of the United Arab Emirates}

The United Arab Emirates (UAE) is a model case of harmonious economic and cultural development almost side-by-side. The UAE is exceptional in many respects. Founded just in 1971 as a union of seven hitherto independent emirates under the protection of Great Britain, an empire at that time, from the early $19^{\text {th }}$ century until the establishment of the new state. It's a small state of 83,600 sq.km with a total population of 9.4 million, male ( 6.80 million) female ( 2.59 million) with a broad age group population of (0 - 14) 14\%, (15 - 24) 11\%, (25 - 59) 72\%, and (60 Plus) $2 \%$ are mostly expatriates from across the globe makes up to $88 \%$ [33]. It has an outstanding liberal leadership which greatly explains the phenomenal economic and cultural development of the country, Ahmed [34]. The transformation is from a desert economy to a highly digital one to developed one. The UAE's economic development is nothing short of a miracle. It is a development "star" of the Arab world, proud of its Arab identity, and of its deeply rooted culture and civilization which it intends to further along with its economic development, which is wholesome and nature respecting.

By 2021, the golden jubilee year of the founding of the state, the UAE is expected to rank among of the highly-developed countries of the world [35]. No wonder, the UAE has been rightly hailed as the "trailblazer" of the Greater Arab World, Rehman [36]. A lot of interest is bestowed, rightly on culture and cultural development with ample cultural dimensions, setting an example for any developing country. The culture of its economic development is nature-and-people friendliness, beneficial to the developing world. The UAE is a trailblazer not only in economic development but also cultural development, giving a wholesome meaning to economic development, which is of rich cultural content without which economic development is not fulsome. There is a cultural renaissance or cultural spring in the nation from literature to sports to entertainment, UAE [37].

The media and cultural sectors are undergoing a period of reorganization, revitalization, and renaissance in the UAE, with particular emphasis on the links between East and West's.

There are special cultural authorities in every province, such as Dubai Culture and Art Authority, Abu Dhabi Authority for Culture and Heritage (ADACH), 
making the ball of culture rolling. There is a vibrant, pan-Arabic Cultural sector covering films, books, book festivals, writers including women writer's union, libraries, research, music, theatre, art galleries, arts, crafts, heritage buildings, archaeology, poetry, painting-an envious sector under the Ministry of Media and Culture, with generous grants and endowments. In fact, culture is the soul of the economic development of the geographically small but economically and culturally giant United Arab Emirates. For the creative and enterprising people, the UAE has an open door and welcome policy among other things, a 10-year visa and residential facilities. It's an oasis of peace and tranquility and economic and cultural creativity amidst the troubled world. Amazingly, there is an AED 1 million envious Arabic poetry prize.

This goal, in sum, is heightening the emirate's culture, almost yearly, with economic advancement. For example, in 2016, the UAE placed a concerted emphasis on culture and the arts, a vision that is dynamically conveyed through numerous cultural platforms, including international book fairs, festivals, art fairs, innovation weeks and The Year for Reading. The country is working meticulously to establish the pillars of a modern economy, one that is built upon the synergy between culture, knowledge, science and industry and which is focused on sustainability and the diversification of national income [38].

The Nation has great pride in its nearly 5000 years of heritage, and in its economic and cultural past. The United Arab Emirates owes its twin developments to its foresighted and visionary founding fathers Sheikh Zayed bin Sultan Al Nahyan of Abu Dhabi and Sheikh Rashid bin Sayeed Al Maktoum of Dubai, and the story of the raising of the new state is presented in the Etihad Museum of Dubai [39]. The Louvre Abu Dhabi champions the cultural achievements of mankind, from prehistory to present day, it combines the UAE's bold vision of cultural progression and openness with France's expertise in the world of Art and museums.

The nation's national buildings as BurjKhalifa (2010) are Arab Architectural marvels. There is a sort of Arab Architectural marvels. There is a sort of Arab architectural renaissance in the United Arab Emirates, which has a liking for everything Arab and is also very considerate of other cultures. It is a global economic and cultural mixing and mingling place. The cultural dimensions of economic development of the UAE have been brought out among others, by As'eed [39].

Can one imagine an Island marked as a Cultural district? The Saadiy at Island in the UAE is such an Island, which gives the amazing story of the Emirates culture from the dawn almost of civilization to the present and the efforts to enhance it in every field from education to Architecture. For example, Arab/Emirate cinema is holding global attention. And the annual Middle East International Film Festival (MEIFF) is a dazzling international offend, proclaiming the arrival of Arab film on the global scene. In sum, the government of the United Arab Emirates is committed to enhancing the Emirates culture from cinema and edu- 
cation to archaeology to Architecture.

\section{Summary, Conclusion, Policy Implication \& Future Research}

\subsection{Summary and Conclusion}

The true worth or importance of culture is its capacity to increase the economic growth and sustainable development, which is the goal of the United Nations for the period 2015-2030. The study, through theory and evidence, establishes a strong case for cultural development as the fourth sector of the economy-culture or cultural sector for fulsome economic development sans or without culture, economic development is untidily. The United Arab Emirates is an eminent example of this, the culture of the Emirates starting with respect to its heritage and environmental protection and accentuation, which is development not at any cost but culture and values based development.

According to the Vice President \& Prime Minister of UAE, H.H. Sheikh Mohammed bin Rashid Al Maktoum "Our culture represents the identity of our generations, and reflects the depth of our history. It is our message that we want to convey to the world in the most creative way. Our Emirati culture promotes the spirit of love, tolerance, and calls for openness to other cultures. The spirit and identity of our culture is inspired from Arab and Islamic civilizations,". "UAE's drive towards leadership of the future, and its pursuit to be among the most advanced countries in the world won't be realized unless we enhance our cultural heritage. The future of our cultural development should be based on creativity and innovation," he said. "Economy, culture and politics are components that interact to create a nation, and build a state... The development of our country depends on a well-established and forward-looking culture." [40]

The UAE is found to be a case of wholesome and fulsome development made up of environmental, human and cultural concerns, which is quite unique. It has a message of culture based development for all developing countries, for development to have values and character. The USA is found to be a good case of economic and cultural development; India's is found to be an in-between case, unable to safeguard its rich cultural heritage products from thefts and smuggling.

\subsection{Policy Implication}

Thus, economic development concluded not to be interpreted to mean just an increase in the production of goods and services over a long period of time resulting in the abundance of goods and services and their full or over-full consumption but also non-material cultural development to give fullness to economic development. The UAE, particularly pursuing this development path, to create a new cultural way. Accordingly, building a two-sector endogenous growth model with the investment in culture can affect economic growth in the long run. The policy implication of the study is to fully take care of the cultural 
sector in economic development and also cultural values. A 4-sector model of economic development is suggested. For example, a high literacy rate and a good educational system, is the first milestone of cultural development.

\subsection{Future Research}

The Rise of Cultural School of Development reinforces the need for cultural development and cultural based economic development, bringing to fore culture in this seemingly materialistic and digital age to public attention, as well as the attention of the policy makers.

\section{Conflicts of Interest}

The authors declare no conflicts of interest regarding the publication of this paper.

\section{References}

[1] Merriam-Webster (2016) The Merriam-Webster Dictionary. Merriam Webster Inc., Springfield.

[2] Smith, A. (1776) An Inquiry into the Nature and Causes of the Wealth of Nations. Rodham.

[3] The Report Sharjah 2017 (2017) Capital of Culture. Oxford Business Group, 10-11.

[4] United Nations (2015) Transforming Our World: The Agenda for Sustainable Development. United Nations, NY.

[5] Florida, R. (2014) The Rise of the Creative Class-Revisited: Revised and Expanded. Basic Books, NY.

[6] Samuelson, P.A. (1983) Foundations of Economic Analysis. Harvard University Press.

[7] Marshall, A. (1920) Principles of Economics: An Introductory Volume. Macmillan, UK.

[8] Malthus, T.R. (1803) An Essay on the Principle of Population. Cosimo Inc., NY (Reprint, 2007).

[9] Ricardo, D. (1817) Principles of Political Economy and Taxation. Barnes and Nobel Books, NY (Reprint 2005).

[10] Marx, K. (1867) Das Kapital. Verlag von Otto Meisner, Hamburg.

[11] Rostow, W.W. (1962) The Stages of Economic Growth. Cambridge University Press, London (Reprint 1991).

[12] Roach, S. (2018) A Chinese Escapade for America's Multilateral Issues. Financial Express, 25 May 2018, 8.

[13] Anstey, V. (1952) The Economic Development of India. Longman, Green and Co. London.

[14] Nehru, J. (1946) The Discovery of India. Signet Press, Calcutta, 67.

[15] Gandhi, M.K. (1947) India of My Dreams. Navajivan Publishing House, Ahmedabad, 3 .

[16] Throsby, D. (2001) Economics and Culture. Cambridge University Press, London.

[17] Tubadji, A. and Nijkamp, P. (2015) Cultural Impact on Regional Development Ap- 
plication of a PLS-PM Model to Greece. The Annals of Regional Science, 54, 687-720. https://doi.org/10.1007/s00168-015-0672-2

[18] Baycan, T. and Nijkamp, P. (2011) A Socio-Economic Impact Analysis of Cultural Diversity, Research Memorandum 2011-12. Faculty of Economics and Business Administration, VU University, Amsterdam.

[19] Bourdieu, P. (1973) Cultural Reproduction and Social Reproduction, Knowledge, Education and Social Change. In: Brown, R., Ed., Papers in the Sociology of Education, Tavistock Publication, 71-112.

[20] Tubadji, A. (2013) Culture-Based Development: Culture and Institutions: Economic Development in the Regions of Europe. International Journal of Society Systems Science, 5, 355-391. https://doi.org/10.1504/IJSSS.2013.058466

[21] Tubadji, A. and Pelzel, F. (2012) Culture Based Development: Measuring an Invisible Resource with PLS-PM Method. International Journal of Social Economics, 42, 1050-1070. https://doi.org/10.1108/IJSE-01-2014-0005

[22] Harrison, L. and Huntington, S. (2000) Culture Matters: How Values Shape Human Progress. Basic Books, New York.

[23] Granato, J., Inglehart, R. and Leblang, D. (1996) The Effect of Cultural Values on Economics Development: Theory, Hypotheses and Some Empirical Tests. American Journal of Political Science, 40, 607-631. https://doi.org/10.2307/2111786

[24] Marini, M. (2004) Cultural Evolution and Economic Growth: A Theoretical Hypothesis with Some Empirical Evidence. Journal of Socio-Economics, 33, 765-784. https://doi.org/10.1016/j.socec.2004.09.044

[25] Tabellini, G. (2005) Culture and Institutions: Economic Development in the Regions of Europe. CESifo Working Paper No. 1492. https://www.cesifo-group.de/DocDL/cesifo1_wp1492.pdf

[26] Bowles, S. (1998) Endogenous Preferences: The Cultural Consequences of Markets and Other Economic Institutions. Journal of Economic Literature, 36, 75-111.

[27] Petrakis, P. and Kostis, P. (2013) Economic Growth and Cultural Change. The Journal of Socio-Economics, 47, 147-157. https://doi.org/10.1016/j.socec.2013.02.011

[28] Schumpeter, J.A. (1934) Theory of Economic Development: An Inquiry into Profits, Capital, Credit, Interest, and the Business Cycle. Harvard University Press, Cambridge.

[29] Kindelberger, C.P. and Herrick, B. (1977) Economic Development. McGraw-Hill, New York.

[30] Economic Times (2018) Budget 2018-19, Feb. 10, 1.

[31] Amponsah, C., Ahmed, G., Othman, S. and Harran, M. () In Search of Global Identity: The Challenges of Culture. The Journal of Human Resource and Adult Learning, 12, 16-28.

[32] Amponsah, C. and Ahmed, G. (2017) New Global Dimensions of Business Excellence. International Journal of Business Excellence, 13, 60-78. https://doi.org/10.1504/IJBEX.2017.085794

[33] United Nations (2017) World Population Prospects. Economic and Social Affairs, New York.

[34] Ahmed, G. (2018) Transformation of UAE from Desert to Developed Economy. Forbes Middle East, Dubai, 29.

[35] Ahmed, G. (2015) Destination 2021. Forbes Middle East, Dubai, 46. 
[36] Rehman, A.A. (2008) Dubai \& Co.: Global Strategies for Doing Business in the Gulf States. McGraw-Hill, New York.

[37] (2009) United Arab Emirates Year Book. Trident Press Ltd., Dubai.

[38] Alkhamis-Kano, H.E. (2017) Abu Dhabi Music \& Arts Foundation Empowering the Nation January-December 2017. Abu Dhabi Music \& Arts Foundation, Abu Dhabi. http://www.admaf.org/en/media/get/20180402_YEAR-BOOK-2017.pdf

[39] As'eed, M.T. and Shorab, Y.M. (2016) Originality and Modernity of Society Emirates. Al Falah Books, Kuwait, 41-48.

[40] Maktoum, M.R. (2018) "Cultural Heritage”, Future of Culture Retreat. Ministry of Culture and Knowledge Management, at the Louvre Abu Dhabi. Vide Gulf News, February 5, 1.

https://gulfnews.com/news/uae/shaikh-mohammad-launches-uae-cultural-develop $\underline{\text { ment-fund-creative-industries-contributions-index-1.2168875 }}$ 